\title{
Land grab/data grab: precision agriculture and its new horizons
}

\section{Alistair Fraser}

To cite this article: Alistair Fraser (2019) Land grab/data grab: precision agriculture and its new horizons, The Journal of Peasant Studies, 46:5, 893-912, DOI: 10.1080/03066150.2017.1415887

To link to this article: https://doi.org/10.1080/03066150.2017.1415887

曲 Published online: 10 Jan 2018.

Submit your article to this journal 준

Џlll Article views: 1219

Q View related articles $₫$

View Crossmark data

Citing articles: 8 View citing articles $ک \pi$ 


\title{
Land grab/data grab: precision agriculture and its new horizons
}

\author{
Alistair Fraser \\ Department of Geography, Maynooth University, Maynooth, Ireland
}

\begin{abstract}
Developments in the area of 'precision agriculture' are creating new data points (about flows, soils, pests, climate) that agricultural technology providers 'grab', aggregate, compute and/or sell. Food producers now churn out food and, increasingly, data. 'Land grabs' on the horizon in the global south are bound up with the dynamics of data grabbing, although hitherto researchers have not revealed enough about the people and projects at issue. Against this backdrop, this paper examines some key issues taking shape, while highlighting new frontiers for research and introducing the concept 'data sovereignty', which food sovereignty practitioners (and others) need to begin considering.
\end{abstract}

\section{KEYWORDS}

Land grab; precision agriculture; big data; food sovereignty; data sovereignty; Ireland

Technology innovations will dramatically reshape how we produce and manage food ... Some of these technologies could be game-changing for food systems, contributing to radically new approaches along the agricultural value chain and beyond. For example, CRISPR [Clustered Regularly Interspaced Short Palindromic Repeats] technology could reinvent seeds, big data and ICT [Information and Communications Technology] could allow for more efficient and climate-smart farming practices, robotics could increase efficiencies in harvest and processing, sensors could reduce waste dramatically in transportation, artificial intelligence could revolutionize retail models, and personalized nutrition could reshape consumers' preferences and behaviours.

— World Economic Forum $(2017,21)$

\section{Introduction}

It is almost a cliché to suggest we are living through a data revolution; that social media, self-driving cars, robots and the like are altering our lives in dramatic ways. Yet considerable action today does point toward far-reaching changes in many spheres of social and economic life. As the above epigraph notes, food production is by no means immune to all this. In fact, on some farms today there are already 'robot farmers' (milking cows, for example), self-driving tractors (guided by satellite to improve fuel efficiency), and various other practices grouped under the term 'precision agriculture' (PA), which refers to techniques that monitor and optimize production processes by advising farmers and/or remotely adjusting machinery to optimally apply fertilizer or chemicals to the land and feed to animals, thereby conceivably increasing yields and outputs and 
improving the efficiency and effectiveness of inputs (Schrijver 2016). ${ }^{1}$ Many of these developments use complex algorithms, lines of software code, proliferating sensors, and numerous computational models to generate, 'crunch', build on and roll out data about human agricultural practices, the lives of animals and the biophysical qualities of land. Sent to the 'cloud' and then stored and manipulated in data farms (in essence, warehouses storing data on computer servers), this new source of information about food production excites commentators on and observers of food production systems - and even leads some to anticipate that PA and 'big data' will 'be the driver of the next revolution in agriculture' (Pineda 2016).

In this paper, my aim is to critically assess these developments with a view to probing what it means for a world increasingly open to (or, at least, familiar with) the core precepts of 'food sovereignty' (e.g. see Wittman, Desmarais, and Wiebe 2010). I locate the emergence of new PA practices against the background of a broader set of processes generating what numerous critical scholars in the area of agrarian studies refer to as a global 'land grab' (e.g. see Zoomers 2010; McMichael 2012). One element underpinning the land grab is the changing relationship between approaches to food production and land use in the global north (and the export-oriented sub-sector of a bifurcated global south; AkramLodhi 2007), and the forms of food production and land use familiar to the 2.5 billion people still involved in farming in the global south. Neatly (if crudely) summed up by the World Bank (2007) as a matter of closing a growing 'yield gap' between capital-intensive and small-scale food production systems, this relationship is not just about differences in yields; rather, today it is also about the nature of backward and forward linkages to technology providers and the technology sector's emerging stake in seeing markets for their services grow, which pivots in large part on global south food producers 'adopting' (read: purchasing) PA goods and services in the coming years. In turn, these dynamics of the land grab need to be understood in relation to the 'spaces of early adoption' in the global north where, as I intend to demonstrate, a contested 'data grab' has become a new battleground over the future of farming. The peril is obvious: the data grab will amplify the global land grab. However, at least one obstacle is the possibility that notions of food sovereignty might embrace and develop what I tentatively refer to as 'data sovereignty' - a scenario $\mathrm{I}$ introduce and discuss in the Conclusion.

\section{The 'data grab'}

Capitalist accumulation in the contemporary period is heavily bound up with action emanating from a 'tech' sector led by firms such as Apple, Alphabet (the owner of Google) and Amazon. Providing goods and services ranging from internet-enabled devices (desktops, laptops, smartphones, etc.) to services including email, social media and internet shopping, these and many other tech firms have been able to gather detailed information about their customers. Numerous other firms - supermarkets or other retailers - and even various government agencies have also begun acquiring similar stores of so-called 'big data' - that is, massive flows and stores of data 'generated continuously, seeking to

\footnotetext{
${ }^{1}$ In the rest of the paper I will continue to use the term 'precision agriculture' rather than related terms such as 'smart agriculture' or 'big data in agriculture'. Both of these alternative terms point toward the same practices and developments highlighted in Schrijver's (2016) definition - data-laden calculations designed to maximise yields - but PA is a more widely used term and captures the essence of the core technological developments at issue in this paper.
} 
be exhaustive and fine-grained in scope, and flexible and scalable in its production' (Kitchin 2014a, 2).

For some of these firms, big data constitutes a resource whose study can help to guide innovation: by studying how we 'swipe' or use a smartphone, for example, device-makers might discover ways of introducing new features that will help them gain market share. Then, for some others, big data becomes an intellectual asset in its own right and increases the firm's market value, thereby attracting buyout bids from other firms. The 2016 purchase by Microsoft of the social networking firm Linkedln for USD 26.2 billion is a prominent case in point: Microsoft wanted intellectual property and knowledge of social media, but also the capacity to learn from and use Linkedln's data set of 430 million users (Hern and Kasperkevic 2016). But an increasingly pervasive element of the big data story concerns the way firms use analysis of big data to build detailed profiles of users, which they can sell to advertisers (the ads that seem to remember what products we have searched for reflect precisely this activity taking place; based on what we do online, numerous other less visible processes are also taking place) (e.g. see Kitchin 2014b). Detailed ongoing analysis of how consumers use devices and services can reveal in-depth insights about what products consumers might buy and how advertisements can lead them to do so.

As such, within contemporary capitalist societies, there is a widespread and persistent generation and then movement of data from individuals (as consumers on devices or as citizens navigating the city or national borders) to firms (and government agencies). For critical scholars, there is significant scope for debate about how that movement of data should be conceptualized. In one sense, because so many of the services generating data today are 'free', there is a tacit understanding that 'free' use occurs precisely because data are collated and then conceivably sold. From this perspective, users are simply involved in a straightforward form of exchange: they get to use the latest software and stay in touch with others in return for giving up a degree of their privacy to firms that consistently proclaim their innocence - or, if not, at least their commitment to using customer information with a view to improving their services or delivering 'better' or 'more relevant' advertisements.

An alternative way to conceptualize this movement of data is to view it as a 'grab', at least insofar as firms (and government agencies) are actively intent on gathering as much data as possible from customers (and from those with whom customers interact online). Per the straightforward notion that grabbing is an opportunistic endeavor, this 'data grab' is about using data to inform innovations and direct strategic investment with respect to a changing context. The result is that billions of dispersed subjects are actively, yet mostly unconsciously, enrolled in an ongoing and expanding process of data grabbing. Tapping into and drawing data from people connecting online now creates numerous opportunities for accumulation, which further fuels the expansion of a basket or suite of services that repeat the process, generating additional data (consider only the unending roll-out of new 'apps' and 'plug-ins', many of them given away for 'free').

Taking stock of action occurring as part of this opportunistic data grab, scholars in critical data studies have argued that a form of dispossession occurs because users lose control of the data they generate. Noting how firms use end-user license agreements 
(EULAs) to 'claim ownership over wide swathes of data', Thatcher, O'Sullivan, and Mahmoudi $(2016,996)$ argue,

Previously public - or, in this case, nonquantified - information about daily life is quantified and privatized, not in the hands of those who generated it, but of those who created the application; whether the espoused motivations for quantification are to enhance the service offered or add value to the dataset being assembled, the transfer of ownership remains.

Subsequently, they state (998), 'Dispossessed of any control of their data, individuals and their individual data points become analyzed and linked together as commodities, their value deriving from the promised ability to produce continual, predictable streams of sales'. However, not only is there dispossession of control; rather, the data grab is a crucial step in a broader, persistent and pervasive process whereby the activities of all customers in networks of social relations generate data with a possible exchange value greater than the sum of its individual parts, yet never receive their share of that value. Gaining control of data can - but will not necessarily (as demonstrated by the numerous stories of failing 'start-ups') - yield profit.

Crucially, moreover, the effects of today's data grab do not end here. Firms grab data and try to add value (by aggregating or packaging); but then they set algorithms to work to target consumers with ads and services, thereby shaping subjectivities in profound and at times nefarious ways (e.g. see Ellenberg 2014; also Pickren 2016). The algorithmic moment (occurring out of sight in dispersed computer servers on the cloud) relies on grabbing and dispossession; but this striking activity is also about actively working to alter society in ways we are only slowly beginning to understand. Today's services and devices engender discriminatory categorization, surveillance, intrusion, loss of privacy (e.g. see boyd and Crawford 2012; Mcllwain 2017), and deepening dependence on (often, offshore) providers accumulating profits from dispersed economies globally (and, in cases of data offshoring, they are generating debates about the possible need for data protectionism; e.g. see Azmeh and Foster 2016).

Numerous constituent elements of data grabbing have been charted and critiqued all across the social sciences (as well as beyond in civil society, the media, etc.; for overviews, see boyd and Crawford 2012; Kitchin 2014b; Pickren 2016). For the most part, however, it is activity of (what we might refer to as) an urban slant that tends to attract the most attention. At issue, for instance, are new data-laden services and practices that alter labor markets (e.g. see Ettlinger 2017) or social life in the so-called 'smart city' (e.g. see Kitchin 2011, 2015; Kitchin, Maalsen, and McArdle 2016). It should come as no surprise that the same processes and practices applying to urban spaces are getting worked out in the agricultural sector. As is widely noted by scholars in agrarian studies (see especially Weis 2007), agricultural producers already depend heavily on the application of inputs, such as (patented) seeds and agri-chemicals. More recently and reflecting the pace of technological development beyond agriculture, transnational corporations such as Monsanto and John Deere have created new products that pivot on the use of devices, sensors and data flows (Bronson and Knezevic 2016). The input 'treadmill' (Weis 2007) is becoming more digital, cloud based and device laden. It is conceivable, as some government reports suggest (e.g. see Schrijver 2016; Teagasc 2016), that PA will help to address purported food production shortfalls as the world moves toward a population of nine 
billion. But alongside its expansion, and indeed an essential component thereof, this new 'data revolution' - this data grab - in agriculture holds out the possibility of altering food production systems and agrarian relations more generally in potentially profound ways. I consider two elements of this scene in the following discussion. The first is about the push for PA in the 'spaces of early adoption' in the global north, which I will consider in the next section of the paper. The second concerns the push into the global south, to which I then turn.

\section{Precision agriculture and the data grab in the spaces of early adoption}

It is possible to identify a data grab in global north agriculture because farmers have purchased PA technologies that monitor, map and manage farm activities, while also generating data for service providers to analyze (and take to market). These products and services reflect the original orientation of PA, which first emerged in the 1980s and 1990s - amidst declining public support for agricultural research and extension and rising competitive pressures on individual farm units - in the form of (what were, at the time) relatively sophisticated technologies to coordinate farm decisions with respect to 'other stages of production, upstream and downstream from the farm' (Wolf and Buttel 1996, 1271). If today's PA technologies have in mind quite similar objectives, they differ by virtue of their capacity to generate and subsequently make use of big data. Today's inputs deepen and extend the original premise of PA by using contemporary technologies. Thus, as Lane Arthur, Director of Digital Solutions in John Deere's Intelligent Solutions Group (ISG), puts it,

Precision agriculture is about getting more from each decision, each job that goes into growing the food we eat. The foundation of that is highly automated farming machines guided by software, GPS [global positioning system] technology and satellites. With subinch accuracy, farmers control the precise placement of seeds and chemicals. They spray precisely the right amount of fertilizer and harvest precisely. Sensors and loT [Internet of Things] make those things possible. (quoted in Puri 2016)

Although a detailed review of the literature on PA-driven farm-level profits reports mixed results (Schimmelpfennig 2016a), a vibrant market exists for sensors, devices, software and data flows united by the vision that PA systems will yield 'more agricultural output with less input' (Schrijver 2016, 30). In the dairy sector, for example, the expansion of socalled 'precision milking' and feeding robots has gathered pace in recent years (Gedders and Adamchuk 2010). Thus, as noted in a Scientific Foresight Study for the European Parliamentary Research Service (Schrijver 2016, 30-31), the

Netherlands, Germany and France are currently leading the shift towards automatic milking. Some $90 \%$ of new equipment installations in Sweden and Finland, and 50\% in Germany include robotic farming. Half of the dairy herds in north-western Europe will be milked by robots in 2025.

Using new inputs such as '[a]utomatic milk feeders for calves [and] online analysis of milk composition, including cell counts (an important index of hygienic condition), fat, protein, and lactose' (Gedders and Adamchuk 2010, 830), dairy farmers expect to see milk yields increase from an EU average of $6915 \mathrm{~kg}$ milk per cow to as much as $12,000 \mathrm{~kg}$, as has been achieved in some demonstration farms (Schrijver 2016, 31). 
Another prominent PA component is auto-steering combines and tractors using guidance systems - 'adopted on 45 to 55 percent of planted acres for several major crops between 2010 and 2013' (Schimmelpfennig 2016b) - that claim to minimize over- and under-application of chemicals, aim to improve seeding, and conceivably reduce operator fatigue. Then there is variable-rate application technology (VRT), which introduces methods of assessing 'the spatial variability of farm parameters related to practices such as tillage, seeding, weeding, fertilization, herbicide \& pesticide application and harvesting' (European Commission 2015a, 71-72). Not yet used to the same extent as guidance systems, VRT was used on only 12 percent of US corn farms smaller than 600 acres in 2010, but 40 percent of farms over 3000 acres (Schimmelpfennig 2016a, 12). PA encourages economies of scale. Finally, there are PA components such as GPS soil and yield mapping; drone mapping; and detailed forms of climate data, a factor leading to Monsanto's purchase of The Climate Corp., a climate data science company, for USD 930 million in 2013 (Bennett 2017).

In these guises, PA feeds into and builds upon diverse Farm Management Information Systems (FMIS) - systems for 'collecting, processing, storing, and disseminating [the data] needed to carry out a farm's operations and functions [and including] specific farmeroriented designs, dedicated user interfaces, automated data processing functions, expert knowledge and user preferences, standardized data communication and scalability' (Fountas et al. 2015, 41) - and other decision support systems (DSS) found across global north agriculture. PA also plugs into data-producing traceability architectures, reflecting in Europe a growing need for 'farmers to demonstrate compliance to the auditing authorities [which thereby increases] the need to implement FMIS aided by automated data collection' (48). Partly at issue here is what scholars in the area of rural studies (e.g. see Hinchliffe et al. 2013) refer to as 'biosecurity'; - that is, the need for farmers to track and trace their outputs and thereby comply with food safety rules such as Europe's General Food Law Regulation (EC) 178/2002 (as well as supermarket-driven governance mechanisms). In theory, at least, PA facilitates and reduces the cost of 'tracking, tracing and documenting' (Schrijver 2016, 31). The underlying notion is that greater digitized scrutiny of production systems via PA will boost food safety. On-farm sensors, for example,

can be used to detect naturally occurring toxins commonly known as mycotoxins in grains, fruits, [and] vegetables, and dangerous pathogens that threaten our food supply. More importantly, these sensors can be used to detect the presence of pathogens or other dangerous agents in foods in less disruptive, more efficient and less costly ways than current sampling methods. (European Commission 2015a, 72)

Beyond biosecurity, PA is promoted by governments and providers as a way to improve feed conversion efficiency. Assumptions that human diets will remain and even become more meat-rich, which pivots on converting plant biomass into animal protein, put pressure on agricultural systems to convert feed more effectively. Against the backdrop of projections that livestock production in 2050 will require an additional 553 million tonnes of grain each year (IAASTD 2009 cited in European Commission 2015b, 52), PA enters into the frame because it holds out the promise of monitoring the lives of animals in more analytical ways, thereby enabling farmers to cater feed operations and minimize waste. At issue is 'optimisation': 'While advances in agriculture have often resulted from innovations on single components (such as breeding, chemical inputs, irrigation technologies), future 
solutions are expected to arise from the optimisation of systems i.e. optimisation of the interplay between their components' (European Commission 2015c, 4).

The new 'technological fix' to agriculture's persistent and 'accelerating biophysical contradictions' (Weis 2010) goes beyond finding new and better chemical inputs by focusing on analyses of on-farm interactions; and on the monitoring, modeling and management of data flows from individual animals, farms as a whole, and system-wide practices.

\subsection{Data: 'the new cash crop'}

Data are a crucial input and output of PA. Robotic milking, for example, 'generates about 120 variables per cow per day such as: movements, feed being distributed, milk being produced, quality of milk, temperature, coughs and other cattle diseases ... ' (Schrijver 2016, 31). And there are the various types of farm machinery in use today, such as the 'Jaguar Forage Harvester made by Claas of America in Sarpy County [which] measures more than 40 parameters as owners operate the machine; the company's Lexion combine tracks and records more than 70' (Epley 2015). The following description of John Deere's mechanisms shed further light on the sort of data flows at issue in PA:

Data from the sensors on the planter is fed to a wireless data server under the seat of the tractor. It pushes the data to the cloud every five seconds. John Deere has its own data centers, but the company also works with public cloud providers such as Amazon Web Services (AWS). Communication with the planter is bidirectional. A seed rep might divide a field into zones based on elevation and soil type. He prepares a 'seed prescription' for the field - similar to a medical prescription. This defines what seeds should be planted and at what spacing on the field. The planting instructions are sent directly to the John Deere planter, which changes the seed planting accordingly. It's highly automated. (Puri 2016)

Thus, even if there are yield gains - more cereals per hectare; more milk per cow - farmers buying PA inputs from agricultural technology providers (ATPs) are also producing data, which ATPs currently are best positioned to collect, store, analyze and sell in bundles or packages that feed into the algorithms of disparate firms involved in agriculture, or not. Data are, in fact, at least for some in the sector, 'the new cash crop' (Tatge 2016), because once they have been aggregated, they have value for seed and chemical firms, agronomists, co-operatives, farm insurance providers and machinery firms. Insofar as farmers sign (or click 'accept' on) EULAs and thereby agree that ATPs can collect their data - quite like those who agree to hand over data in return for using email or social media services - PA accelerates and amplifies the data grab. For some observers, then, too many farmers continue to be unaware 'of all the ways in which a company intends to use their farm data' (Clark 2016).

By no means does the story end here. There have been debates about data stewardship (i.e. data ownership, security/protection, and privacy; see Archer and Delgadillo 2016) within the agricultural sector and, in response, the American Farm Bureau has sought to create guidelines regarding data access, control, and information disclosure for ATPs (Epley 2015). Working with ATPs such as Dow AgroSciences LLC, DuPont Pioneer, John Deere and Monsanto, and various farmers' institutions, the Farm Bureau has recently produced 'data principles', an 'Ag Data Transparency Evaluator', and a new interface called the ADAPT Toolkit, which 'will allow each equipment manufacturer to keep its own proprietary software and technology in the cab and monitor, but will allow participating companies to 
"export to" and "import from" a common, open-source ADAPT file format' (Grassi 2017; also see Farm Bureau 2017). As Lane Arthur from John Deere suggests,

Data is extremely valuable. John Deere believes farmers should control the data generated by their operations. This involves deciding who it should be shared with. For example, a farmer could decide to share data from one field or only share data from one planting season with a partner. (Puri 2016, emphasis added)

These initiatives reflect awareness that ATPs are well positioned to create valuable data sets without sharing revenues with farmers, but also that ATPs want to be perceived as doing so in a way that builds trust with farmers. Per a Scientific Foresight Study for the European Parliament: 'Making farmers the owners of their data and providing opportunities to control the flow of their data to stakeholders should help build trust with farmers for exchanging data and harvest the fruits of the analysis of big data' (Schrijver 2016, 9). The catch-all term used widely in these debates about control is 'open' or 'transparent' data; in the EU an Open Data Directive and at G8 level an Open Data Charter (see Teagasc 2016, 41, emphases added) are indications of efforts to streamline and standardize 'data stewardship'.

Yet, even if agricultural data are 'open', farmers are not necessarily equipped to conduct the right sort of analysis that can add any value: a series of data points is one thing, but knowing how to analyze or create new models (and having the computing power and time to do so) is another thing entirely. Moreover, data about one farm operation have only limited value as compared to when data about numerous farms is aggregated (e.g. see Ellixson and Griffin 2017). As Jiménez et al. (2016) point out, 'the value of information obtained from farmers' experiences and controlled experiments is enhanced [by] modern data mining techniques [that] can establish relationships and associations between observations from multiple sources, which farmers can use to improve their crop husbandry' (14, emphasis added). What ATPs see before them is the possible emergence of a landscape in which farmers submit data, even via open toolkits, that only the largest firms will be able to use effectively. In the case of Monsanto's subsidiary The Climate Corp., for example, the machine-learning capabilities of its systems (algorithm-based software which learns from its own mistakes) can scan images taken from fields to 'quickly process the disease present in the image and give the grower the proper diagnosis of the pathogen' (Bennett 2017); but this is about machine learning capabilities that will be massively improved once its platform is connected to food production on 300 to 400 million acres, rather than its current 100 million acres (Plume 2016).

\subsection{PA's other emerging tensions}

If the data question is one emerging area of dispute regarding PA, there are some notable others. One is the possibility that PA will alter the overall market for agricultural inputs, with uncertain consequences for actors upstream of the farm. At issue is that PA differs from the markets for agricultural chemicals and farm machinery insofar as the barriers to entry for some products are much smaller, which means there is scope for smallscale suppliers to capture market share from the sector's corporate giants. For example, farmers with the right skills and/or determination (and without having to write code) can purchase and operate relatively cheap equipment such as drones fitted with cameras and sensors. Indeed, some guidance systems on farm machinery have been 
developed by small firms such as Sixty-5 Technologies in Belfast - in this case, a singleband receiver on the roof of a tractor (McCullough 2016). In celebratory tones, therefore, some commentators suggest the data revolution, including new high-quality (and, for Europeans, free) satellite imagery, is driving down costs so much that the 'sky is the limit for agricultural technology' (Tasker 2016).

Another emerging debate concerns the link between farmers, PA, buyers, markets and prices. Supermarkets exert pressure on food producers to upgrade equipment merely to remain within the supply chain. But the costs of moving into PA are 'sunk costs' and are not recoverable - unlike farm machinery, for example, there is a small resale market for many PA inputs (Schimmelpfennig 2016a, 13) - hence farmers absorb start-up costs at risk they will not see the expected benefits. Even if PA does deliver gains, they may be offset in the long run if improved yields do indeed deliver higher output but conceivably also lower output prices. Either way, the growth of PA engenders and deepens a digital divide between the most capital-intensive farms and those unable or unwilling to embrace contemporary technologies. Its adoption might therefore give further impetus to the growth of larger farm holdings - a process already well developed in the US and now a growing feature of European agriculture, given an annual rate of decline in the number of farms of 3.7 percent between 2005 and 2013 (Schrijver 2016, 6). In effect, PA complicates concepts of rurality constituted by small-scale farmers, which remain bound up with popular notions of national identity across Europe and in the US. Moreover, the potential significance of PA cannot be understated precisely because of the contested nature of 'post-productivist' rural spaces today - spaces, that is, that are projected in some places (especially Europe) to remain a public good accessible to urban dwellers but yet also central to a ramped-up export-oriented production complex targeting increased animal protein consumption in Asian markets. A central attraction of PA in Europe is its promise to boost output and enable farmers to target export markets, while also enabling an overall decline in the area of farmed land over the next few decades. In play here, therefore, is the role of PA in altering the emerging relationship between global north agriculture and food production in the global south, as demonstrated in the following brief discussion of PA in Ireland's export-oriented agricultural sector.

\section{3. 'Data is the new soil': PA, export agriculture and the Irish 'ag-tech' model}

The Irish government has aggressively encouraged dairy and livestock exports as a component of its attempted fix of a debt- and crisis-ridden economy now undergoing a period of 'recovery' amid a broader structural adjustment (or, as it is referred to in Ireland, an 'austerity') program. Exports are absolutely central to the fate of dairy and livestock producers in Ireland, many of whom are banking on not only continued access to the global marketplace but growing protein consumption in Asia.

In alignment with this export push, the Irish government views its nascent 'ag-tech' sector as key players in a rising global market for PA-related inputs. As noted by Teagasc (the Irish national government's body for research, advisory and training services to the agriculture and food industry) in a flagship report, Technology Foresight 2035,

Innovative Irish companies are already serving domestic farmers and farmers around the world with a range of technologically advanced products and services, including data- 
driven services that help farmers improve profitability based on real-time advice on animal health and nutrition ... Ireland is a technology hub of choice for the strategic business activities of eight of the top ten global ICT companies and we also have a growing indigenous digital technology sector with sales of over $€ 2 \mathrm{bn}$ per annum. Many of these companies are already working with Teagasc and its partners to develop next generation technologies and systems to improve productivity and reduce the environmental impact for agri-food producers. Their ultimate goal is to export these systems and services to rapidly growing markets around the world .... (Teagasc 2016, 24, emphasis added)

Accordingly, if Ireland is to become a 'global leader', if it is going to 'take global leadership', the Teagasc report suggests 'there is a need to bring these players around the table to develop a national strategy for an export-oriented agri-digital industry' (24). Not only will Irish farmers need to play their part - 'New technologies and farming systems will only contribute adequately to a globally sustainable Irish agri-food and bioeconomy sector if adoption rates [among Irish farmers] are improved' (26, emphasis added) - but this will be an export push in which the state will play a prominent role (much like the 'strategic coupling' which Asian states use as a way to pair workers with manufacturing transnational corporations and their global production networks; e.g. see Coe et al. 2004; Lee, Heo, and Kim 2014).

A crucial consideration here is the Irish state's extant pro-enterprise stance, which it has cultivated over the last 20 years in particular (e.g. Breathnach 2010), and which it uses to extend venture funding (a subsidy, in all but name) via Enterprise Ireland (the state's agency seeking to support Irish businesses) to Irish PA firms. A case in point is GrassOmeter, an Irish-designed device used to measure grass growth. And indeed, as one of its designers noted, at issue in this field of investment is not so much the devices and their value to users but rather the possibilities they open up for data analysis:

Once you are gathering data, that data has got value for fertiliser companies and seed firms so there is a bigger interest there than just the individual farmer ... Data is the new soil: it's as important for the farm of the future as the tractor is today. As technology progresses, you are able to measure things and manage things in ways that you couldn't do before. Increasingly that data is going to be as important as the crops that are harvested. (Steve Lock, quoted in Independent 2015, emphasis added)

The presence of the Irish state and its ag-tech firms in the field of PA is bound up with efforts to locate the Irish economy as a supplier of PA inputs to the global market and as an analyzer of the data. In this regard it is worth noting that Irish 'data farms' are already among the largest and most efficient in the world, which has proved useful in attracting some of the tech sector's largest firms to establish European headquarters there (a low corporation tax rate has also helped). In courting these firms via the Irish Development Authority, the Irish state's vehicle for attracting inward investment, the country has created a pool of talent and expertise in the technology sector, a factor which has fed into the growth of Irish ag-tech firms. One such firm, Keenan, runs InTouch, a 'cloud platform which enables real-time access to on-farm and supply chain data for the management of animal performance, health and nutrition' (Teagasc 2016, 42). InTouch collects data from sensors on 'over 3000 farms across the world' - nutritionists interpret the data in Ireland and then give advice to farmers, thereby advising them to 'make better feed and nutrition decisions in the management of their animals, so as to drive performance and profitability'. 
Thus, in one model of Ireland's future, PA firms transfer data collected in sub-Saharan Africa or Asia and then process it in Ireland. By virtue of doing so, they learn not only about agricultural practice globally but also how overall procedures can be made into new intellectual property (and conceivably patented). In another model, Irish ag-tech firms develop new PA technologies that attract larger firms, leading to partnerships, strategic alliances and conceivably buyouts (in this regard, it is revealing that the US-based privately held animal health company AllTech recently purchased Keenan, in 2016; Brennan 2016). Ultimately, on the agenda for all of these actors is the globalization of PA and the prospect of taking part in the emerging data grab, which the Irish state and its PA firms view as a viable strategy for their future. From their vantage point, in a wealthy export-oriented country in the global north, one with a strong agricultural sector benefitting from persistent support from the EU's Common Agricultural Policy (e.g. see Fraser 2011), Irish PA entrepreneurs, designers and investors look out on the global south and see scope for growth. Opportunity knocks. It is, then, in the notion embedded within the PA story that 'data is the new soil' - that data can become a new cash crop; that the sky is the limit - that I suggest the global south really starts to come into view. As I have noted, there are dynamics about PA specific to the global north: issues of power, process and profit projections among ATPs, which pivot on farm businesses embracing or becoming compelled into buying PA inputs. Some of these dynamics spill over into the global south. But the specificity of PA in the global south really seems to stand out with respect to processes associated with the land grab, as I now discuss.

\section{The 'data grab' as a component of 'land grabs' in the 'global south'}

Talk of a 'global land grab' calls attention to the prospect of a shift, endorsed by the World Bank (2007), toward more capital-intensive agriculture and increases in average farm sizes in the global south. Driven by external agents, including sovereign wealth funds (Zoomers 2010), 'national capital' (e.g. see Byres 2016), and dramatic as well as more gradual land acquisitions (or state-sanctioned expropriations), land grabs intersect with an enduring food system or regime, which is nevertheless characterized by emergent features and forces, including projections about rising demand for protein amidst growing affluence in $\mathrm{Asia}^{2}$ or the changing fortunes of and complex dynamics involved in using agricultural land to produce specific commodities, such as biofuels (Vermeulen and Cotula 2010; also Clapp, Isakson, and Visser 2017). In this part of the paper, my aim is to assess the role PA and the data grab are playing within this scene.

PA products and services are already common in some parts of the 'bifurcated' global south, especially on large-scale farms within capital-intensive 'export-oriented sub-sectors' (Akram-Lodhi 2007). In Brazil's soybean sector, for example, guidance systems and VRT are widely used (Silva, Ferraz Dias de Moraes, and Molin 2011). Such practices immediately raise questions about the way data are generated and used. There is the prospect of data moving offshore to be processed, aggregated and sold in the US without Brazilian soybean producers receiving any share of the product. In this regard, Brazilian soybean farmers occupy a similar position to farmers in the US, although matters to do with the

\footnotetext{
${ }^{2}$ But only if governments globally continue to reject the possibility of limiting such demand, for example via forms of meat rationing, a dramatic intervention but one that would recognize the planetary limits to this type of dietary change (see Weis 2013).
} 
legal infrastructure might alter those dynamics: Brazil established a Civil Rights Framework for the Internet in 2014 (e.g. see Archer and Delgadillo 2016). Nevertheless, investment from the global north is occurring, such as US-based agricultural data firm AGDATA acquiring PRG Brazil AG in 2015, which signals corporate interest in expanding the frontiers of PA and pushing on with the data grab (AGDATA 2015).

Furthermore, in what Akram-Lodhi (2007) refers to as the peasant sub-sector in the global south - that is, on those pieces of land in the firing line of the land grab - PA is now becoming part of the scene. Some PA applications to highlight here are relatively low-tech and might therefore be considered to create data-neutral dynamics: microdosing fertilizer in Niger, precision leveling in Uttar Pradesh and devices such as GreenSeeker in Mexico (van Kark 2014). ${ }^{3}$ VRT, however, is a different entity. Consider that Raj Khosla, a plant scientist and PA specialist based in Colorado, has highlighted nitrogen variability on farms as small as 1.5 hectares: 'Where yields were higher, plants were removing more nutrients. We've seen variability on less than a third of a hectare of land' (quoted in van Kark 2014). The types of innovations developed in places such as Ireland devices and services like the aforementioned GrassOmeter - are pertinent examples of how VRT might begin entering into the frame in the peasant sub-sector. Indeed, as noted by Mark Rosegrant, Director of the Environment and Production Technology Division at the International Food Policy Research Institute (IFPRI),

using smaller scale sensors and machinery in places like India, South Africa, China, and after that, countries in Southeast Asia are already you're finding the uses of these kind of smaller-scale precision agriculture which boosts yield significantly, but also then reduces run-off of nitrogen, volatilization of that into greenhouse gases, as well, as well as reducing water use, which is essential. (Rosegrant 2014)

Given these sorts of developments, it makes sense to identify and examine interactions between the data and land grabs. Hitherto, however, the dynamics at work in the expansion of PA and specifically its relationship with 'big data', the digital economy, and the data revolution have not received attention in debates about the emergence of a global land grab - although 'big data' has emerged in analyses of the 'rush' to write about it (e.g. see Zoomers, Gekker, and Schafer 2016; also Oya 2013).

Yet in Millar's (2016) fascinating research on a 'bio-ethanol plantation covering 40,000 hectares of agricultural land in the rural north of Sierra Leone' (6), one key dynamic is highlighted which connects fruitfully with the materials I have been grappling with in this paper. Specifically, Millar flags the importance to contemporary investors of land registers, surveys and maps, as well as digital knowledge in the form of satellite imagery, GPS coordinates and geographic information systems (GIS). The company's use of these materials and data flows, Millar finds, 'contributed to the diffusion of corporate power over local land and people [by dissociating] information regarding land from the dynamic social contexts in which it is located [and thereby serving] to marginalize local people from the operation of power' (15). Regarding similar contexts, Li (2015) draws attention to processes of 'assembling', whereby information, knowledge and data (about area, crops, yields) are used as a form of 'inscription' to render land investible, which then allows investors to

\footnotetext{
${ }^{3}$ It is unclear whether guidance systems in farm machinery will make a big impact given their expense and focus on large farm sizes, although even here, with falling prices for components and new applications arriving on the market, guidance systems are by no means entirely off limits.
} 
more effectively calculate risk and develop strategies to put investment plans into place. At issue here is 'asset-making', which requires that investors can make assessments based on data about soil quality or the availability of water (Visser 2017); as new portions of land enter into contemporary financial calculations - as they are viewed, assessed and exchanged in distant markets - there is a growing need for, and increased importance of, data. Thus, whereas land grabs in the colonial period were cartographically oriented to document altitude, the flow of rivers, the variability in soils and the potential existence of mineral deposits (e.g. see Scott 1998), land grabs in the twenty-first century will pivot on digital knowledge. Putting investment plans into place today - knowing where to go, what to expect to find there, what the lay of the land will be like, what constitutes the terrain requires data (for example, for the simple purpose of using computer-aided design (CAD) software to build warehouses, offices, or model transportation or other flows of materials). Land grabbing needs data.

A similar logic is at work in the geographical expansion of PA. At issue is a drive to acquire digital knowledge that can inform its roll-out, which will then generate scope to harvest new data sources. As noted earlier, ATPs and PA providers are already learning extensively about global north spaces. As they try to achieve their ambitions of exporting services and devices to the global south - and before they can begin harvesting 'the new crop' of data therein - they need to acquire information and knowledge about those spaces. The contemporary expansion of PA across the global south hinges on (and targets) data. For example, for the designers, the innovators or the venture capitalists in places such as Ireland and beyond, growing the market for PA inputs (raising the venture capital; making the right investments) means they need data on the places into which their products will be exported. Satellite imagery does go some of the way here; however, the crucial 'last mile' when it comes to PA is the micro-scale details about soils, nutrients, watercourses or climate. Whether via a freeware model or by leasing devices using micro-credit, with users (potentially, unwittingly) handing over data about their land, the expansionist logics of PA demand that ATPs accumulate additional layers of topographical, topological (flows inward and outward; links, connections and relations with suppliers and buyers, markets and government), and even social data (farmer practices, rates of technology adoption, customer feedback). If the globalization of PA is to continue, and if users in the global south are to become the next wave of customers, data must flow.

In short, the land grab targets land (or water; Mehta, Veldwisch, and Franco 2012); but the land itself (its shape, dimensions and topography) is only an initial block of data for ATPs and PA product developers. From the perspective of ATPs, the promise of the land grab is not only that new capitalist farmers might emerge and begin purchasing inputs, but also that the micro-scale qualities of land and lives potentially will be fed into the data analytics infrastructures run by these firms (or aggregated, packaged and sold on by them). ATPs stand to piece together a rich (and valuable) cartography and database from which new understandings of soil variability, nitrogen and climate might emerge (conceivably, forms of knowledge they will be able to patent).

None of this should appear fanciful. The logics at work are quite clearly evident. There is already pressure on producers globally to comply with food safety standards, which compels farmers to adopt (at least basic elements of) PA architectures as a way to remain in the supply chain (e.g. see Knox, Kay, and Weatherhead 2012). The 'efficiency' 
gains and apparent biosecurity merits of PA approaches spill over and get pushed into distant locales, thereby putting additional pressure on food producers to 'modernize' and comply with standards set in distant territories, or exit the market. In doing so, these producers are already caught up in the data grab. Then there is the need among ATPs to expand their markets. The suppliers of PA inputs, like the suppliers of other agricultural inputs, are always under pressure from their shareholders to strategize and find new outlets where the greatest scope for growth exists. And alongside this pressure there is the matter of the tech sector's momentum to consider here. For example, developments such as so-called 'machine learning' aim to identify soils or pests, or to determine the 'correct' application of chemicals, but these approaches will only succeed if the algorithms are fed data. In turn, the 'crunching' - the analysis, the twisting and crafting of algorithms - taking place off-farm (indeed, potentially offshore, per the Irish model noted above), and not necessarily by data analytics firms in the agricultural sector, will generate scope for additional innovations, new applications and new devices. The land grab yields a data grab; and in an as-yet poorly understood and complex manner, its beneficiaries demand that new data points and providers are created and then harvested. Indeed, a central part of the novelty regarding PA and the wider algorithmic world we can see taking shape around us is the apparently limitless scope for data analysis and data grabbing to occur: so long as there is life, action and a flow of materials, there are opportunities for firms in the data analytics sector to put algorithms to work - to model and make potentially lucrative markets from the analysis of seemingly mundane practices. If (the data producing potential of today's 2.5 billion small-scale food producers in the global south are now in the viewfinder of the PA or 'ag-tech' sector, their position with respect to the dynamics charted in this paper deserves critical attention from scholars in the area of peasant and agrarian studies.

\section{Conclusion: toward data sovereignty}

This paper has explored features of an emerging terrain in which robot farmers, selfdriving tractors, sensors and tracking devices are proliferating. Fascinating developments regarding these variants of so-called precision agriculture are certainly taking place. What these developments will yield, in the end, remains far from certain. But there are clear indications that the data grab - building on the formation of new products, services and markets that pivot on dispossessing agricultural producers of control over and possibly value emerging from data they produce - will grow via geographical expansion: by targeting sales to distant food producers and enrolling them in data-generating processes that provide materials to be analyzed and brought to market, potentially also with scope for patents to emerge that privatize (conceivably, as-yet-unknown) steps or practices around food production. Much of this expansion will occur in the export-oriented subsector within the bifurcated rural spaces of the global south. But even the mostly subsistence, smallholder sub-sector will come into view. If a 'land grab' continues to unfold in front of us, it is going to occur alongside elements of a 'data grab'.

The challenge now, then, is to contest data grabbing. Per notions of food sovereignty (e.g. see Wittman, Desmarais, and Wiebe 2010) and related concepts such as 'seed sovereignty' (Kloppenburg 2010), I would like to conclude by tentatively proposing the need for deliberation regarding a concept we might fruitfully refer to as 'data sovereignty'. As the 
above materials have indicated, simply connecting to the online world today generates data points for firms to crunch, analyze, add value to and sell. If food producers enter into new relations with agricultural technology providers (ATPs), they become exposed to the data grab, perhaps unwittingly and then with uncertain consequences given the gestational phase of this market. Against this backdrop, data sovereignty requires that actors in civil society, or in cooperative economic associations, develop principles and practices that explore whether the emergent value of data should be held in common, rather than privatized; destroyed, rather than analyzed and brought to market; or stored nearby, rather than exported.

Crucially, however, and in accordance with Kloppenburg's (2014) qualification of biotechnology and corporate biotechnology, data sovereignty should not mean complete rejection of all aspects of PA, simply because there is a flow of data. Technology will live with us in the twenty-first century (witness the extraordinary growth and popularity of smartphones over the last few years). But there are (widely discussed, widely used) alternative software architectures that enable users to sidestep the data grab. Using an open-source operating system (OS) running variants of Linux, rather than the Apple or Microsoft variants, is one step. Using an open-source encrypted email service such as Protonmail is another. For cloud storage, users can turn to Boxcryptor, or create their own 'cloud' via network-attached storage (NAS) systems. For instant messaging, Signal. At issue here is adopting a principle that inconvenience - slower speeds, for instance ${ }^{4}$ might be a necessary step toward refusing the invitation to enroll in data grabbing architectures and related systems and practices that marketize social life via near-invisible algorithmic dispossession.

For food producers in the contemporary period, simply because an element of farming practice might generate data is no reason to reject it outright; at issue, instead, is developing an understanding of how that data is used, or whether or not users can 'hack it', much as is proposed by the group Farm Hack (Carolan 2017a) or by those who see opportunities to develop alternative PA hacks (Carolan 2017b). The challenge is to contest or manipulate PA with a view to achieving food sovereignty without contributing to the data grab. The objective of data sovereignty is to contest how the globalization of technology architectures (around food production or regarding other areas of social life) takes shape (see also Couldry and Powell 2014; Baack 2015). There is a need now to imagine, discover and pursue ways of incorporating questions of how we deal with data into the questions we raise about the prospects for food sovereignty in the twenty-first century.

Some indications of what might be needed here emanate from actions by farmers in the US. The Grower Information Services Cooperative, for example, claims to be the agricultural sector's 'only grower-run data cooperative' (GISC 2017). According to its Chief Executive Officer (CEO), Jason Ward, GISC is '“a cooperative [...] We're farmer-owned and we have a high level of trust with our members"' (Vogt 2017). GISC has now joined with the Agricultural Data Coalition, which was formed by farmers and allies in law, business, engineering and academic research. Together they have established AgXchange which is 'designed as an open, central point of access' for farm data. It is, they claim, 'a neutral platform for the grower to control how their data is shared'; an initiative 'dedicated

${ }^{4}$ Like slow food, 'slow computing' has some merit. 
to creating the agriculture industry's first cloud-based platform that will be controlled by growers and open to all industry service partners and technology providers' (AgProExchange 2017). In short, AgXchange is about finding ways of stopping the data grab, and it reflects the deep concern among some farmers that ATPs will grab and use farm data for their own purposes. It is emblematic of actions intended to reuse the invitation to enroll in systems and practices that marketize social life via near-invisible algorithmic dispossession. Data sovereignty entails developing initiatives along similar lines. ${ }^{5}$ At the very least, there is a strong case to be made for food producers and their associations in the global north and south examining how initiatives such as AgXchange operate and evaluating what they achieve.

Emphatically, however, the overall task of pursuing something along the lines of data sovereignty is not going to be straightforward. In the first place, for those assessing or creating food sovereignty as an answer to many of the most pressing social challenges today - hunger, climate change, corporate power - the matter of what happens to data might simply seem like a minor issue: even if our lives are bound up with computing, the significance of the data we produce can appear to be a marginal dynamic in a violent, oppressive world. Moreover, although the offer of 'free' software services is too good to be true; as an offer it is, nevertheless, still a good offer, at least for a great many people. Yet, so long as users of contemporary technology services participate and remain dispossessed of the value emerging from the data points our daily activities generate, we not only risk new forms of corporate control over society ${ }^{6}$ we also acquiesce which is, I suggest, a far cry from (any notion of) sovereignty.

\section{Acknowledgement}

The author would like to thank Nancy Ettlinger, Rob Kitchin, and the two anonymous reviewers for helpful comments and suggestions on earlier drafts. Any errors and omissions are my own.

\section{Disclosure statement}

No potential conflict of interest was reported by the authors.

\section{Funding}

This paper did not receive any research funding.

\section{Notes on contributor}

Alistair Fraser is a lecturer in the Department of Geography at Maynooth University, Ireland. He holds a PhD in geography from the Ohio State University, USA. His first book is Global foodscapes: oppression and resistance in the life of food (Routledge, 2017). Other works include articles in the Journal of Rural Studies, Environment \& Planning A and Geoforum. Email: Alistair.Fraser@mu.ie

\footnotetext{
${ }^{5}$ And requires supporters of food sovereignty to probe the limits of coalitions with the private sector (contractors, consultants, providers of 'data farms', etc.).

${ }^{6}$ The rise of tech giants might hold out the promise that they will not be evil, as Google once promised, but their track records suggest otherwise. Besides, shareholder value, growth and profit margins are what will always matter, in the final instance.
} 


\section{References}

AGDATA. 2015. "AGDATA Acquires PRG Brazil AG." AGDATA, March 20, 2015. https://www.agdata. com/newsroom/agdata-acquires-prg-brazil-ag.

AgProExchange. 2017. About. https://agproexchange.com/about/.

Akram-Lodhi, A. H. 2007. "Land, Markets and Neoliberal Enclosure: An Agrarian Political Economy Perspective." Third World Quarterly 28 (8): 1437-1456.

Archer, J. K., and C. A. Delgadillo. 2016. "Key Data Ownership, Privacy and Protection Issues and Strategies for the International Precision Agriculture Industry." Proceedings of the 13th international conference on precision agriculture. http://www.huschblackwell.com/industries_ services/precision-agriculture\#tab/insights.

Azmeh, S., and C. Foster. 2016. The TPP and the Digital Trade Agenda: Digital Industrial Policy and Silicon Valley's Influence on New Trade Agreements. London School of Economics International Development Working Paper Series. http://www.lse.ac.uk/international-development/Assets/ Documents/PDFs/Working-Papers/WP175.pdf.

Baack, S. 2015. "Datafication and Empowerment: How the Open Data Movement Re-articulates Notions of Democracy, Participation, and Journalism." Big Data \& Society. doi:10.1177/ 2053951715594634.

Bennett, D. 2017. "Climate Corporation Wants to Push Precision AG to New Heights." Delta Farm Press, January 20, 2017. http://www.deltafarmpress.com/technology/climate-corporation-wants-pushprecision-ag-new-heights.

boyd, D., and K. Crawford. 2012. "Critical Questions for Big Data: Provocations for a Cultural, Technological, and Scholarly Phenomenon." Information, Communication \& Society 5 (12): 662 679. doi:10.1080/1369118X.2012.678878.

Breathnach, P. 2010. "From Spatial Keynesianism to Post-Fordist Neoliberalism: Emerging Contradictions in the Spatiality of the Irish State." Antipode 42 (5): 1180-1199. doi:10.1111/j. 1467-8330.2010.00798.x.

Brennan, J. 2016. "Alltech Confirms Purchase of Keenan Systems." Irish Times, April 22, 2016. http:// www.irishtimes.com/business/agribusiness-and-food/alltech-confirms-purchase-of-keenansystems-1.2621229.

Bronson, K., and I. Knezevic. 2016. "Big Data in Food and Agriculture." Big Data \& Society. doi:10.1177/ 2053951716648174.

Byres, T. J. 2016. "In Pursuit of Capitalist Agrarian Transition." Journal of Agrarian Change 16 (3): 432 451. doi:10.1111/joac.12176.

Carolan, M. 2017a. "Agro-Digital Governance and Life Itself: Food Politics at the Intersection of Code and Affect." Sociologia Ruralis 57: 816-835. doi:10.1111/soru.12153.

Carolan, M. 2017b. "Publicising Food: Big Data, Precision Agriculture, and Co-Experimental Techniques of Addition." Sociologia Ruralis 57 (2): 135-154. doi:10.1111/soru.12120.

Clapp, J., S. R. Isakson, and O. Visser. 2017. "The Complex Dynamics of Agriculture as a Financial Asset: Introduction to Symposium." Agriculture and Human Values 34 (1): 179-183.

Clark, P. 2016. "Opinion: Growers shouldn't Need a Law Degree to Understand their Data Terms Agreements." Agri-Pulse, July 14, 2016. https://www.agri-pulse.com/articles/7259-opiniongrowers-shouldn-t-need-a-law-degree-to-understand-their-data-terms-agreements.

Coe, N. M., M. Hess, H. W. C. Yeung, P. Dicken and J. Henderson. 2004. "'Globalizing' Regional Development: A Global Production Networks Perspective." Transactions of the Institute of British Geographers 29 (4): 468-484. doi:10.1111/j.0020-2754.2004.00142.x.

Couldry, N., and A. Powell. 2014. "Big Data from the Bottom Up." Big Data \& Society. doi:10.1177/ 2053951714539277.

Ellenberg, J. 2014. "What's Even Creepier than Target Guessing that You're Pregnant?" Slate, June 9, 2014. http://www.slate.com/blogs/how_not_to_be_wrong/2014/06/09/big_data_what_s_even_ creepier_than_target_guessing_that_you_re_pregnant.html.

Ellixson, A. C., and T. Griffin. 2017. Farm Data - Ownership and Protections. AREC Fact Sheet 1055. http://umaglaw.org/download/farm-data-ownership-protections/. 
Epley, C. 2015. "Ag Data Considered a Vital Crop, But Who Actually Owns It?" Omaha World-Herald, March 15, 2015. http://www.omaha.com/money/ag-data-considered-a-vital-crop-but-whoactually-owns/article_fdf19438-8441-5343-a557-9eec6f8c4b72.html.

Ettlinger, N. 2017. "Open Innovation and its Discontents." Geoforum; Journal of Physical, Human, and Regional Geosciences 80: 61-71. doi:10.1016/j.geoforum.2017.01.011.

European Commission. 2015a. Preparing the Commission for Future Opportunities. Foresight Netwoks fiches 2030 working document. http://ec.europa.eu/newsroom/dae/document.cfm?action= display\&doc_id=9423.

European Commission. 2015b. Sustainable Agriculture, Foresty and Fisheries in the Bioeconomy: A Challenge for Europe. European Commission 4th Foresight excercise. http://bookshop.europa. eu/en/sustainable-agriculture-forestry-and-fisheries-in-the-bioeconomy-pbKI0115295/.

European Commission. 2015c. Towards a Long-term Strategy for European Agricultural Research and Innovation by 2020 and Beyond. https://ec.europa.eu/agriculture/sites/agriculture/files/expomilano-2015/cap-events/long-term-vision/background_en.pdf.

Farm Bureau. 2017. Privacy and Security Principles for Farm Data. http://www.fb.org/issues/ technology/data-privacy/privacy-and-security-principles-for-farm-data.

Fountas, S., G. Carli, C. G. Sorensen, Z. Tsiropoulos, C. Cavalaris, A. Vatsanidou, B. Liakos, et al. 2015. "Farm Management Information Systems: Current Situation and Future Perspectives." Computers and Electronics in Agriculture 115: 40-50. doi:10.1016/j.compag.2015.05.011.

Fraser, A. 2011. "'Nothing Less than its Eradication'? Ireland's Hunger Task Force and the Production of Hunger." Human Geography 4 (3): 48-60.

Gedders, R., and V. I. Adamchuk. 2010. "Precision Agriculture and Food Security." Science 327 (5967): 828-831. doi:10.1126/science.1183899.

GISC. 2017. Home Page. https://www.gisc.coop/.

Grassi, M. J. 2017. AgGateway: We Encourage Equipment Manufacturers to Adopt ADAPT. http://www. precisionag.com/systems-management/data/aggateway-we-encourage-oems-to-adopt-adapt/.

Hern, A., and J. Kasperkevic. 2016. “Linkedln bought by Microsoft for $\$ 26.2 \mathrm{bn}$ in Cash." The Guardian, June 13 2016. https://www.theguardian.com/technology/2016/jun/13/linkedin-bought-bymicrosoft-for-262bn-in-cash.

Hinchliffe, S., J. Allen, S. Lavau, N. Bingham, and S. Carter. 2013. "Biosecurity and the Topologies of Infected Life: From Borderlines to Borderlands." Transactions of the Institute of British Geographers 38 (4): 531-543. doi:10.1111/j.1475-5661.2012.00538.x.

IAASTD. 2009. Agriculture at a Crossroads. IAASTD Global Report. Washington, DC: International Assessment of Agricultural Knowledge, Science and Technology for Development. http://www. fao.org/fileadmin/templates/est/Investment/Agriculture_at_a_Crossroads_Global_Report_ IAASTD.pdf.

The Independent. 2015. "Irish Inventors Driving the High-tech Farm of the Future." The Independent, May 24, 2015. http://www.independent.ie/business/technology/irish-inventors-driving-thehightech-farm-of-the-future-31248410.html.

Jiménez, D., H. Dorado, J. Cock, S. D. Prager, S. Delerce, A. Grillon, M. Andrade Bejarano, H. Benavides, and A. Jarvis, 2016. "From Observation to Information: Data-Driven Understanding of on Farm Yield Variation." PLOS ONE. doi:10.1371/journal.pone.0150015.

Kitchin, R. 2011. "The Programmable City." Environment and Planning B - Planning \& Design 38 (6): 945-951. doi:10.1068/b3806com.

Kitchin, R. 2014a. "Big Data, New Epistemologies and Paradigm Shifts." Big Data \& Society. doi:10. 1177/2053951714528481.

Kitchin, R. 2014b. The Data Revolution: Big Data, Open Data, Data Infrastructures and Their Consequences. London: Sage.

Kitchin, R. 2015. "Making Sense of Smart Cities: Addressing Present Shortcomings." Cambridge Journal of Regions, Economy and Society 8 (1): 131-136. doi:10.1093/cjres/rsu027.

Kitchin, R., S. Maalsen, and G. McArdle. 2016. "The Praxis and Politics of Building Urban Dashboards." Geoforum; Journal of Physical, Human, and Regional Geosciences 77: 93-101. doi:10.1016/j. geoforum.2016.10.006. 
Kloppenburg, J. 2010. “Impeding Dispossession, Enabling Repossession: Biological Open Source and the Recovery of Seed Sovereignty." Journal of Agrarian Change 10 (3): 367-388. doi:10.1111/j.14710366.2010.00275.x.

Kloppenburg, J. 2014. "Re-purposing the Master's Tools: The Open Source Seed Initiative and the Struggle for Seed Sovereignty." Journal of Peasant Studies 41 (6): 1225-1246. doi:10.1080/ 03066150.2013 .875897$.

Knox, J. W., M. G. Kay, and E. K. Weatherhead. 2012. "Water Regulation, Crop Production and Agricultural Water Management - Understanding Farmer Perspectives on Irrigation Efficiency." Agricultural Water Management 108: 3-8. doi:10.1016/j.agwat.2011.06.007.

Lee, Y. S., I. Heo, and H. Kim. 2014. "The Role of the State as an Inter-scalar Mediator in Globalizing Liquid Crystal Display Industry Development in South Korea." Review of International Politcal Economy 21 (1): 102-129. doi:10.1080/09692290.2013.809781.

Li, T. M. 2015. “Transnational Farmland Investment: A Risky Business." Journal of Agrarian Change 15 (4): 560-568.

McCullough, C. 2016. "Grass-Guide GPS System Offers Guidance on a Budget." Farmers Weekly, March 25, 2016. http://www.fwi.co.uk/machinery/grass-guide-gps-system-offers-guidance-on-a-budget. $\mathrm{htm}$.

Mcllwain, C. 2017. "Racial Formation, Inequality and the Political Economy of Web Traffic." Information, Communication \& Society 20 (7): 1073-1089.

McMichael, P. 2012. "The Land Grab and Corporate Food Regime Restructuring." Journal of Peasant Studies 39 (3-4): 681-701. doi:10.1080/03066150.2012.661369.

Mehta, L., G. J. Veldwisch, and J. Franco. 2012. "Introduction to the Special Issue: Water Grabbing? focus on the (re)appropriation of Finite Water Resources." Water Alternatives 5: 193-207.

Millar, G. 2016. "Knowledge and Control in the Contemporary Land Rush: Making Local Land Legible and Corporate Power Applicable in Rural Sierra Leone." Journal of Agrarian Change 16 (2): 206-224. doi:10.1111/joac.12102.

Oya, C. 2013. "Methodological Reflections on 'Land Grab' Databases and the 'Land Grab' Literature 'Rush'." Journal of Peasant Studies 40 (3): 503-520. doi:10.1080/03066150.2013.799465.

Pickren, G. 2016. “'The Global Assemblage of Digital Flow' Critical Data Studies and the Infrastructures of Computing." Progress in Human Geography. Advance online publication. doi:10.1177/ 0309132516673241.

Pineda, S. 2016. "A Team that's Bringing the Big Data Revolution to Agriculture." CIAT Blog, August 4, 2016. http://blog.ciat.cgiar.org/a-team-thats-bringing-the-big-data-revolution-to-agriculture/.

Plume, K. 2016. "Monsanto's Climate Corp to Expand Digital Farming Platform." Reuters, August 17, 2016. http://www.reuters.com/article/us-monsanto-farming-data-idUSKCN10S1Q4.

Puri, D. 2016. "John Deere Leads the Way with loT-driven Precision Farming." Network World, November 30, 2016. http://www.networkworld.com/article/3145640/internet-of-things/growingmore-with-less-john-deere-leads-the-way-with-iot-driven-precision-farming.html.

Rosegrant, M. 2014. "Agriculture and Technology: Improving Farming, Food Security, and Funding. Technology on the Menu: Food of the Future [Transcript]." Council on Foreign Relations, November 3, 2014. http://www.cfr.org/food-security/agriculture-technology-improving-farmingfood-security-funding/p35763.

Schimmelpfennig, D. 2016a. Farm Profits and Adoption of Precision Agriculture. Washington, DC: United States Department of Agriculture. https://www.ers.usda.gov/webdocs/publications/ err217/err-217.pdf? $v=42661$.

Schimmelpfennig, D. 2016b. "Precision Agriculture Technologies and Factors Affecting Their Adoption." Amber Waves, December 5, 2016. https://www.ers.usda.gov/amber-waves/2016/ december/precision-agriculture-technologies-and-factors-affecting-their-adoption/.

Schrijver, R. 2016. Precision Agriculture and the Future of Farming in Europe. Brussels: Scientific Foresight Unit, European Parliamentary Research Service. http://www.europarl.europa.eu/ RegData/etudes/STUD/2016/581892/EPRS_STU(2016)581892_EN.pdf.

Scott, J. C. 1998. Seeing Like a State: How Certain Schemes to Improve the Human Condition have Failed. New Haven, CT: Yale University Press. 
Silva, C. B., M. A. Ferraz Dias de Moraes, and J. P. Molin. 2011. "Adoption and Use of Precision Agriculture Technologies in the Sugarcane Industry of São Paulo state, Brazil." Precision Agriculture 12 (1): 67-81. doi:10.1007/s11119-009-9155-8.

Tasker, J. 2016. "Sky is the Limit for Agricultural Technology." Farmers Weekly, February 26, 2016.

Tatge, J. 2016. "Data is the New Cash Crop: Understanding the Market for Farm Data." The Dirt, October 3, 2016. https://dirtforfarmers.com/data-is-the-new-cash-crop-understanding-themarket-for-farm-data-59056dda285d\#.09pryvuhj.

Teagasc. 2016. Teagasc Technology Foresight 2035. https://www.teagasc.ie/media/website/ publications/2016/Teagasc-Technology-Foresight-Report-2035.pdf.

Thatcher, J., D. O'Sullivan, and D. Mahmoudi. 2016. "Data Colonialism through Accumulation by Dispossession: New Metaphors for Daily Data." Environment and Planning D: Society and Space 34 (6): 990-1006.

van Kark, C. 2014. "From Agribusiness to Subsistence: High-tech Tools Now Available to All." The Guardian, June 4, 2014. https://www.theguardian.com/global-development-professionalsnetwork/2014/jun/04/subsistence-farming-precision-agriculture.

Vermeulen, S. and L. Cotula. 2010. "Over the Heads of Local People: Consultation, Consent, and Recompense in Large-scale Land Deals for Biofuels Projects in Africa." Journal of Peasant Studies 37 (4): 899-916. doi:10.1080/03066150.2010.512463.

Visser, O. 2017. "Running out of Farmland? Investment Discourses, Unstable Land Values and the Sluggishness of Asset Making." Agriculture and Human Values 34 (1): 185-198.

Vogt, W. 2017. "Digging in to New Data Coalition Deal." Farm Industry News, March 7, 2017. http:// www.farmindustrynews.com/technology/digging-new-data-coalition-deal.

Weis, T. 2007. The Global Food Economy: The Battle for the Future of Farming. London: Zed Books.

Weis, T. 2010. "The Accelerating Biophysical Contradictions of Industrial Capitalist Agriculture." Journal of Agrarian Change 10 (3): 315-341. doi:10.1111/j.1471-0366.2010.00273.x.

Weis, T. 2013. The Ecological Hoofprint: The Global Burden of Industrial Livestock. London: Zed Books.

Wittman, H., A. A. Desmarais, and N. Wiebe. 2010. Food Sovereignty: Reconnecting Food, Nature and Community. Oxford: Pambazuka.

Wolf, S. A., and F. H. Buttel. 1996. "The Political Economy of Precision Farming." American Journal of Agricultural Economics 78 (5): 1269-1274.

World Bank. 2007. World Development Report 2008: Agriculture for Development. Washington, DC: World Bank.

World Economic Forum. 2017. Shaping the Future of Global Food Systems: A Scenarios Analysis. http:// www3.weforum.org/docs/IP/2016/NVA/WEF_FSA_FutureofGlobalFoodSystems.pdf.

Zoomers, A. 2010. "Globalisation and the Foreignisation of Space: Seven Processes Driving the Current Global Land Grab." Journal of Peasant Studies 37 (2): 429-447. doi:10.1080/ 03066151003595325.

Zoomers, A., A. Gekker, and M. T. Schafer. 2016. "Between Two Hypes: Will 'Big Data' Help Unravel Blind Spots in Understanding the 'Global Land Rush?'" Human, and Regional Geosciences 69: 147-159. doi:10.1016/j.geoforum.2015.11.017. 